\title{
MULTIMEDIA INTERAKTIF SEBAGAI MEDIA VISUALISASI DASAR-DASAR ANIMASI
}

\author{
Firdausy Armansyah, Sulton, Sulthoni \\ Jurusan Teknologi Pendidikan, Fakultas Ilmu Pendidikan, Universitas Negeri Malang \\ Jl. Semarang 5 Malang 65145-0341-5747001 \\ firdausy97@gmail.com
}

\begin{tabular}{|c|c|}
\hline Article History & Abstrak \\
\hline $\begin{array}{l}\text { Received: June, } 20^{\text {th }} .2019 \\
\text { Accepted: August, } 16^{\text {th }} 2019 \\
\text { Published: August, } 31^{\text {st }} \\
2019\end{array}$ & 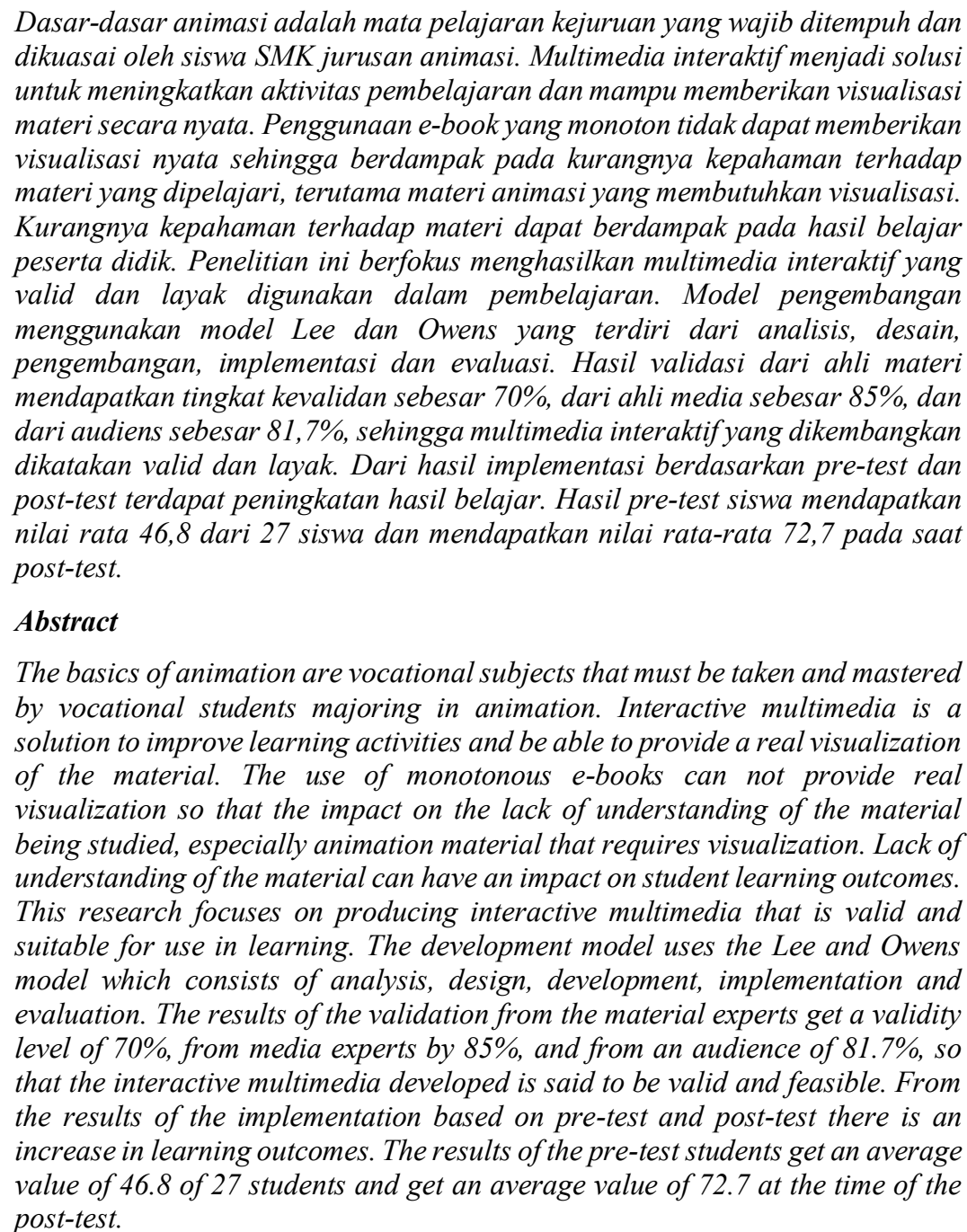 \\
\hline
\end{tabular}




\section{PENDAHULUAN}

Multimedia merupakan salah satu media pembelajaran yang menggabungkan beberapa elemen media yang dipresentasikan dalam media komputer. Multimedia interaktif adalah solusi dalam memudahkan siswa mempelajari materi dibandingkan dengan buku teks/e-book yang monoton. Dalam penelitian Farida \& Rahayu (2017) menunjukkan adanya perbedaan hasil belajar signifikan dalam penggunaan multimedia interaktif daripada menggunakan buku teks.

Multimedia interaktif materi dasar-dasar animasi dikembangkan berdasarkan kebutuhan lapangan. Permasalahan di lapangan menunjukkan bahwa tingkat pemahaman siswa dalam materi dasar-dasar animasi masih tergolong rendah jika dilihat dari hasil belajar peserta didik. Disebabkan karena materi dasar-dasar animasi hanya disajikan dalam buku bacaan yang berformat pdf. Penyajian materi dalam bentuk teks bacaan tidak dapat memberikan visualisasi nyata tentang materi dasar-dasar animasi. Materi dasar-dasar animasi akan susah dipahami jika tidak disertai dengan visualisasi. Hal ini berdampak pada rendahnya hasil belajar peserta didik.

Pengembangan multimedia interaktif diharapkan bisa membantu siswa meningkatkan hasil belajarnya melalui pemanfaatan multimedia. Multimedia interaktif yang dikembangkan memiliki keunggulan mudah dioperasikan, siswa bisa memilih materi yang diinginkan, menggunakan kontrol yang sistematis dalam belajar (Munir, 2008). Menurut Azhar (2002) menjelaskan bahwa media pembelajaran bisa memperjelas penyajian pesan/informasi/materi sehingga dapat meningkatkan proses dan hasil belajar serta memperlancar belajar siswa.

\section{METODE}

Penelitian ini menggunakan model pengembangan Lee dan Owens (2004) terdiri dari lima langkah yaitu, analisis, desain, pengembangan, implementasi dan evaluasi.

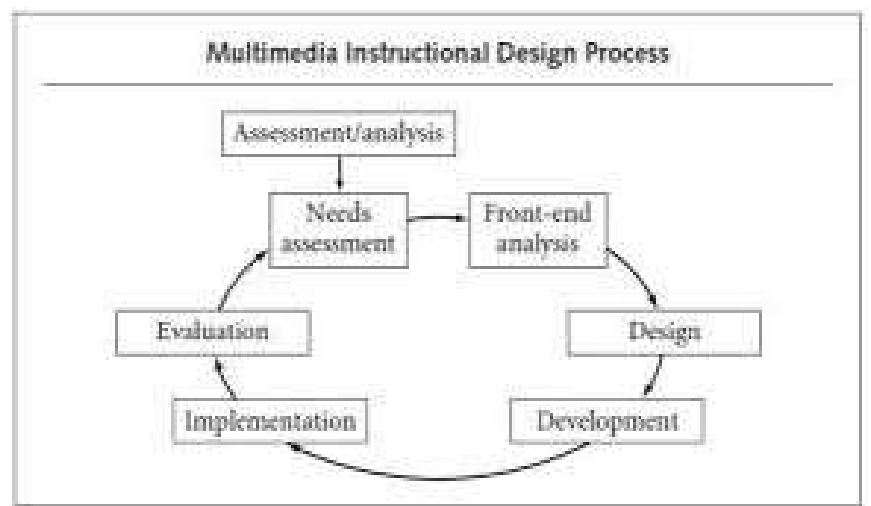

Gambar 1. Model Penelitian dan Pengembangan William W. Lee dan Diana L. Owens (2004) (Sumber: Lee \& Owens, 2004: xxviii)

Subjek penelitian ini terdiri dari 27 siswa kelas XI Animasi SMKN 5 Malang.

Pengumpulan data dilakukan melalui wawancara dan angket. Wawancara dilakukan untuk mengetahui media yang dimanfaatkan dalam pembelajaran. Angket digunakan untuk menilai kevalidan multimedia interaktif yang dikembangkan. Untuk menguji efektivitas, peneliti menggunakan pre-test dan post-test. Analisis data yang digunakan adalah kualitatif dan kuantitatif. Data kualitatif didapat dari hasil wawancara dan data kuantitatif didapat dari hasil angket yang dilakukan oleh para ahli. 


\section{HASIL}

Multimedia ini terdiri dari beberapa bagian komponen materi, yaitu cover, tujuan pembelajaran, daftar materi, tampilan materi, closing.

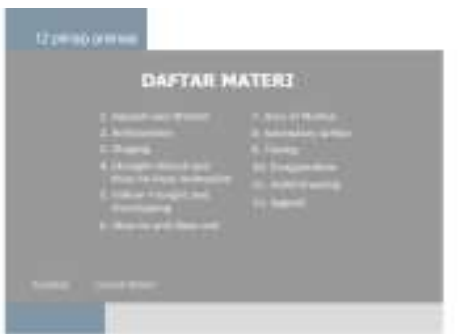

Gambar 2. Tampilan daftar materi

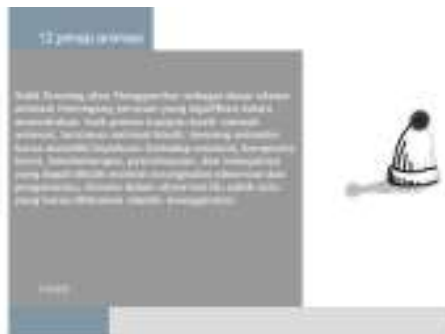

Gambar 3. Tampilan materi 12 prinsip animasi

Tingkat kevalidan produk yang digunakan berdasarkan tingkat kelayakan/kevalidan menurut Arikunto (2006).

Tabel 1. Kriteria Tingkat Kelayakan (Arikunto, 2006:274)

\begin{tabular}{cccc}
\hline Kategori & Prosentase & Kualifikasi & Ekuivalen \\
\hline A & $80 \%-100 \%$ & Valid & Layak \\
B & $60 \%-79 \%$ & Cukup Valid & Cukup Layak \\
C & $40 \%-59 \%$ & Kurang Valid & Kurang Layak \\
D & $0 \%-39 \%$ & Tidak Valid & Tidak Layak
\end{tabular}

Berdasarkan dari hasil penilaian angket kelayakan multimedia berdasarkan penilaian dari para ahli, mendapatkan tingkat kevalidan/kelayakan dari penilaian ahli materi sebesar $70 \%$, dari ahli media sebesar $85 \%$, dan dari audiens sebesar $81,7 \%$. Penilaian dari validator menunjukkan bahwa multimedia interaktif yang dikembangkan ini masuk dalam kategori yang layak digunakan atau valid dalam pembelajaran.

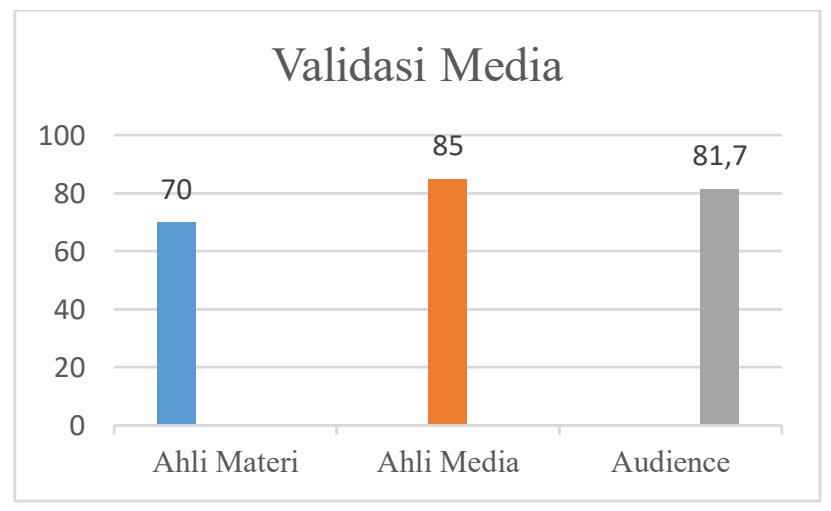

Gambar 4. Hasil validasi media

Dari hasil uji coba media terhadap subjek penelitian, peneliti memberikan pre-test dan post-test untuk melihat perkembangan hasil belajar peserta didik sebelum dan sesudah menggunakan multimedia interaktif. Nilai pre-test subjek penelitian mendapatkan nilai rata-rata 46,8 dan mendapatkan nilai rata-rata 72,7 pada saat post-test. Hasil ini menunjukkan bahwa multimedia interaktif yang dikembangkan cukup efektif dalam meningkatkan hasil belajar peserta didik. 


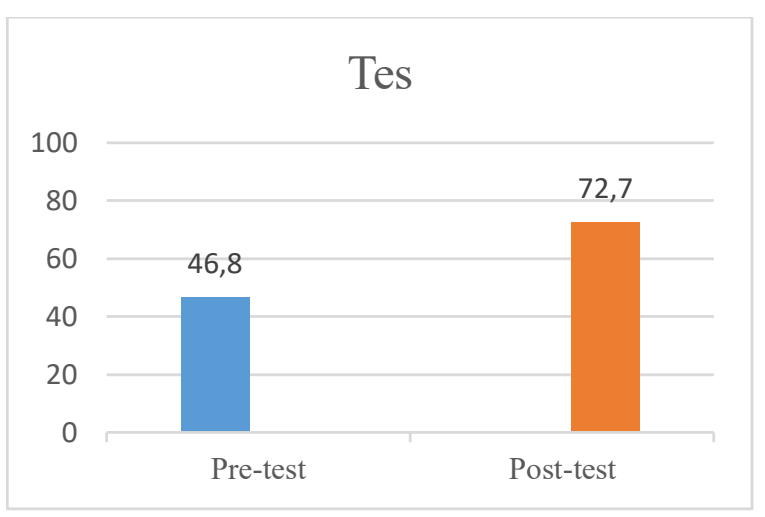

Gambar 5. Hasil implementasi media

\section{PEMBAHASAN}

Multimedia menurut Robin dan Linda dalam Darmawan (2011:47) adalah alat yang menciptakan presentasi yang dinamis dan interaktif yang mengkombinasikan grafik, teks, animasi, video dan audio. Multimedia mempunyai kegunaan memperjelas penyajian materi supaya tidak terlalu visual, mengatasi keterbatasan ruang, waktu, dan daya indera, serta dapat mengatasi sikap pasif siswa (Sadiman, dkk, 2010: 17-18). Multimedia interaktif dapat mengubah materi yang sifatnya abstrak menjadi konkret, serta dapat memberikan siswa partisipasi aktif dalam pembelajaran, mendapatkan pengalaman nyata, mengamati kejadian dalam media dalam bentuk simbol (Trinawindu, dkk, 2016)

Multimedia interaktif berbasis animasi bisa memperjelas penyajian materi, memperlancar proses pembelajaran, mengarahkan perhatian, menimbulkan motivasi, memungkinkan pembelajaran secara mandiri, sehingga dapat meningkatkan hasil belajar peserta didik berdasarkan penelitian yang dilakukan oleh Agustina (2016). Penelitian Sukiyasa (2013) juga menjelaskan tentang media interaktif berbasis animasi mempunyai pengaruh signifikan terhadap hasil belajar peserta didik. Penelitian tersebut menjelaskan bahwa menggunaan multimedia interaktif berbasis animasi dapat memberikan hasil belajar lebih tinggi daripada menggunakan multimedia presentasi.

Penelitian lain yang dilakukan oleh Fauziah, dkk (2016) menunjukkan bahwa penggunaan multimedia interaktif telah terbukti efektif untuk meningkatkan motivasi dan hasil belajar peserta didik. Sejalan dengan penelitian tersebut, penelitan yang dilakukan oleh Nurlaela, dkk (2016) juga menunjukkan adanya efektivitas dalam penggunaan multimedia interaktif untuk meningkatkan hasil belajar peserta didik. Penelitian Nusir (2013) juga membuktikan efektivitas penggunaan multimedia interaktif bisa meningkatkan hasil belajar peserta didik dibandingkan dengan pembelajaran tradisional.

Selain meningkatkan hasil belajar peserta didik, multimedia interaktif juga bisa meningkatkan keterampilan berpikir kritis berdasarkan penelitian yang dilakukan oleh Retnosari, dkk (2016). Untuk menciptakan multimedia yang efektif untuk siswa, guru mempunyai peranan sangat penting dalam mengembangkan aplikasi multimedia interaktif mereka sendiri (Babiker, 2015). Multimedia interaktif yang dikembangkan memiliki karakteristik interaktif dan mudah dioperasikan dapat menjadikan siswa berinteraksi langsung dengan materi dalam media.

Multimedia interaktif dapat menjadi solusi dalam pembelajaran, karena memudahkan siswa dalam mempelajari materi. Multimedia interaktif yang dikembangkan merupakan rangkuman dari seluruh materi yang disajikan dalam bahan ajar yang diberikan oleh guru. Multimedia interaktif memiliki tampilan yang dinamis sehingga bisa menjadi daya tarik tersendiri untuk siswa kalau 
dibandingkan dengan teks bacaan yang disajikan dalam format pdf. Multimedia interaktif ini juga bisa meningkatkan imajinasi siswa dengan visualisasi animasi yang disajikan.

Multimedia interaktif merupakan fasilitas pembelajaran secara mandiri tanpa dibantu guru. Multimedia interaktif bersifat fleksibel sehingga siswa dapat memilih mempelajari materi sesuai dengan keinginannya. Multimedia interaktif ini berisi materi 12 dasar animasi menyediakan materi disertai visualisasi nyata dasar-dasar animasi tersebut, sehingga memudahkan siswa untuk memahami konsep materi 12 dasar animasi. Multimedia interaktif yang dikembangkan bisa memberikan visualisasi nyata dari materi 12 dasar animasi, sehingga memudahkan siswa untuk memahami materi.

Visualisasi merupakan teknik pembelajaran yang dapat menjadikan suatu konsep materi dapat dilihat dengan indera penglihatan secara nyata (Harsalinda \& Wijayati, 2018). Arsyad (2014: 102) menjelaskan bahwa visualisasi materi yang akan disampaikan dapat disajikan dalam bentuk foto/gambar/ilustrasi, grafik, sketsa,bagan, chart. Pendidikan visualisasi adalah metode simulasi, dimana dibuat dan dipresentasikan melalui media komputer untuk memberikan suatu tampilan tertentu (Andoro, 2015).

Meningkatnya pemahaman siswa melalui visualisasi materi dalam multimedia interaktif ini bermaksud untuk membantu meningkatkan hasil belajar peserta didik. Hal itu terbukti dari hasil uji coba lapangan terkait pemanfaatan multimedia interaktif dalam pembelajaran yang menunjukkan meningkatnya hasil belajar peserta didik setelah menggunakan multimedia interaktif ini. Efektivitas multimedia untuk pembelajaran yang dikembangkan bisa dilihat dari hasil pre-test dan post-test yang diberikan kepada siswa. Nilai siswa pada saat pre-test mendapatkan nilai rata-rata 46,8 dan mendapatkan nilai rata-rata 72,7 pada saat post-test.

Hasil itu menunjukkan multimedia interaktif yang dikembangkan terbukti efektif digunakan dalam pembelajaran. Visualisasi materi dalam multimedia interaktif ini terbukti efektif untuk meningkatkan pemahaman konsep peserta didik terhadap materi 12 dasar animasi sehingga terdapat peningkatan nilai peserta didik sebelum dan sesudah penggunaan multimedia interaktif. Selain mampu meningkatkan hasil belajar, multimedia interaktif ini bisa meningkat motivasi siswa dalam belajar, dilihat dari respon siswa terhadap media.

Meningkatnya motivasi peserta didik untuk mempelajari materi dengan memakai multimedia interaktif bisa menjadi salah satu contoh referensi untuk guru dalam mengembangkan media pembelajaran untuk pembelajaran materi yang lain. Multimedia interaktif bisa menjadi alternatif media pembelajaran yang dapat menjadikan pembelajaran lebih hidup dan tidak monoton. Multimedia interaktif juga bisa dikombinasikan dengan metode dan model yang tepat dengan kebutuhan pembelajaran agar pembelajaran tidak terkesan membosankan.

\section{SIMPULAN}

Penelitian pengembangan ini berfokus untuk menghasilkan multimedia interaktif yang layak digunakan dan valid dalam pembelajaran serta efektif dalam membantu meningkatkan hasil belajar peserta didik. Penilaian validator materi sebesar $70 \%$, penilaian dari validator media sebesar $85 \%$, dan penilaian dari audiens sebesar $81,7 \%$. Hasil ini menunjukkan jika multimedia tutorial yang dikembangkan layak digunakan dan valid. Uji coba pada lapangan terhadap subjek penelitian menunjukkan meningkatnya hasil belajar sebelum dan sesudah pemakaian multimedia, dari nilai rata-rata 46,8 pada saat pre-test menjadi mendapatkan nilai rata-rata 72,7 pada saat post-test dari 27 siswa. 


\section{REFERENSI}

Agustina, A. (2016). Pembelajaran Konsep Ikatan Kimia dengan Animasi Terintegrasi LCD Projector Layar Sentuh (Low Cost Multi Touch White Board). Jurnal Tadris Kimiya. 1(1), 8-13 . Retrieved from http://www.journal.uinsgd.ac.id/index.php/tadris-kimiya/article/view/1163

Andoro, I. F. B. (2015). Proses Visualisasi Sistem Operasi Berbasis Multimedia dengan Metode Kognitif Piaget di SMK Ibu Kartini Semarang. Jurnal IC-Tech. 10(2), 52-59. Retrieved from https://jurnal.stmikwp.ac.id/files/disk1/2/ictech--ignfbayuan-58-1-7bayu.pdf

Arikunto, S. (2006). Prosedur Penelitian Suatu Pendekatan Praktek. Jakarta: PT Renika Cipta.

Azhar, Arsyad. (2002). Media Pembelajaran. Jakarta: Rajawali press.

Babiker, M. E. A. (2015). For Effective Use of Multimedia in Education, Teachers Must Develop their Own Educational Multimedia Applications. Turkish Online Journal of Educational Technology - TOJET. 14(4), 62-68. Retrieved from https://eric.ed.gov/?id=EJ1077625

Darmawan, Deni. 2014. Inovasi Pendidikan: Pendekatan Praktik Teknologi Multimedia dan Pembelajaran Online. Bandung: PT Remaja Rosdakarya.

Fauziah, F. (2016). Efektivitas Penggunaan Multimedia Interaktif Terhadap_Motivasi Dan Hasil Belajar Siswa di SMP pada Mata_Pelajaran IPS. Jurnal Teknologi Pendidikan dan Pembelajaran. 1(1), 26-37. Retrieved from https://journal.institutpendidikan.ac.id/index.php/tekp/article/download/92/94

Harsalinda, R. (2018). Visualisasi Sebagai Upaya untuk Memahami Materi Teoritis di Dalam Perkuliahan. Journal Deutsch als Fremdsprache in Indonesian. 2(1), 1-14. Retrieved from http://journal2.um.ac.id/index.php/dafina/article/view/2592

Lee, W. W., \& Owens, D. L. (2004). Multimedia -Based Instructional Design. San Fransisco: Pfeiffer.

Munir. (2008). Kurikulum Berbasis Teknologi Informasi dan Komunikasi. Bandung: ALFABETA

Nurlaela. (2016). Efektivitas Penggunaan Multimedia Pembelajaran Interaktif Melalui Pendekatan CTL dalam Meningkatkan Hasil Belajar Siswa Tentang Pesawat Sederhana pada Pembelajaran IPA di Kelas V Sekolah Dasar Negeri Hanjuang I. 1(1), 48-59 . Retrieved from https://journal.institutpendidikan.ac.id/index.php/tekp/article/download/94/96

Nusir, S. (2013). Studying the Impact of Using Multimedia Interactive Programs on Children's Ability to Learn Basic Math Skills. Sage Journals. 10(3), 305-319. Retrieved from https://journals.sagepub.com/doi/abs/10.2304/elea.2013.10.3.305

Sadiman. (2010). Media Pendidikan: Pengertian, Pengembangan dan Pemanfaatannya. Jakarta: PT. Raja Grafindo Persada.

Sukiyasa, K. (2013). Pengaruh Media Animasi Terhadap Hasil Belajar dan Motivasi Belajar Siswa_Materi Sistem Kelistrikan Otomotif. Jurnal Pendidikan Vokasi. 3(1), 126-137. Retrieved from https://journal.uny.ac.id/index.php/jpv/article/download/1588/1318

Retnosari, N. (2016). Pengaruh Model Pembelajaran Inkuiri Terbimbing Berbantuan Multimedia Interaktif Terhadap Berpikir Kritis Siswa Kelas XI SMA Negeri di Bojonegoro. Jurnal Pendidikan. 1(8), 15291535. Retrieved from http://journal.um.ac.id/index.php/jptpp/article/view/6635

Trinawindu, I. B. K. (2016). Multimedia Interaktif untuk Proses Pembelajaran. Jurnal Prabangkara. 19 (23), 35-42 . Retrieved from https://jurnal.isi-dps.ac.id/index.php/prabangkara/article/view/135/75 